Acta Scientifica Naturalis

Former Annual of Konstantin Preslavsky University - Chemistry, Physics, Biology, Geography Journal homepage: asn.shu.bg

Received: 02.2019

Accepted: 03.2019

\title{
In-vivo Antidiarrhoeal and anti-ulcerative activities of the Tetraclinis articulata species of the Cupressaceae family
}

Zine El Abidine Ababsa ${ }^{1,2}$, Mohamed Tahar Derouiche ${ }^{3}$, Kamel Medjroubi ${ }^{2}$, Salah Akkal ${ }^{2}$.

${ }^{1}$ Department of Sciences of Matter, Faculty of Natural Sciences and Life, Larbi BEN M'HIDI

University, Oum El Bouaghi-Algeria (ababsapharm@gmail.com

${ }^{2}$ Unit for the Valorization of Natural Resources, Bioactive Molecules and Physico-Chemical and Biological Analyzes, Faculty of Exact Sciences, Department of Chemistry, Mentouri University of Constantine 1- Algeria

${ }^{3}$ Faculty of Medicine, Department of Pharmacy, University Salah BOUBNIDER of Constantine 03. Algeria.

\begin{abstract}
Tetraclinis articulata (Thuy of Barbary), endemic to North Africa, is used as a traditional medicine for the treatment of many diseases [1]. We investigated the antidiarrhoel properties of the butanol extract of Tetraclinis articulata (BETA) in male and female Swiss albino mice to support its traditional use. The antidiarrhoeal activity of the plant extract was evaluated in a model of castor oilinduced diarrhoea model in mice and compared to loperamide (a reference inhibitor of diarrhoea) .The effect of (BETA) on gastrointestinal motility was determined by the oral administration of charcoal and Castrol oil-induced intestinal fluid accumulation (enteropooling).The (BETA) showed remarkable antidiarrhoeal activity significantly inhibited gastrointestinal motility and castor oil induced enteropolysis $(68,18 \%)$, more than to the inhibition achieved in loperamide treated mice (60,16\%). The second aim of the present study was to evaluate the anti-ulcerative activity of The (BETA), it produced percent protection of control colitis by $77,40 \%$, while the standard drug (aspirin) produced $\mathbf{8 1 , 3 9 \%}$ protection. We conclude that Tetraclinis articulata extracts are potential sources of new anti-ulcer agents and antidiarrhoeal drugs.
\end{abstract}

Keywords: Tetraclinis articulate, n-butanol extract, antidiarrhoeal activity, anti- ulcerative activity.

\section{Introduction:}

Tetraclinis articulata TA (Thuya of Barbary), endemic to North Africa, covering approximately 1 million hectares in the three countries of the Maghreb (Algéria, Morocco and Tunisia) [1].

In Morocco, local people use this tree species in medicine traditional, to treat various types of diseases, including those of the cardio-vascular system [2]. Throughout Morocco, studies have been carried out on the traditional pharmacopoeia and medical practices in general [3].Various parts of this tree are used for its multiple therapeutic effects, it is mainly used against childhood [4], respiratory and

50

Corresponding author: ababsapharm@gmail.com

DOI: 10.2478/asn-2019-0007

C2019 “K. Preslavsky”University of Shumen. All rights reserved 
intestinal infections [5], gastric pains [6], diabetes, hypertension [7], antidiarrheal, antipyretic, diuretic, antirheumatic and oral hypoglycemic [8].

\section{Materials and Methods}

\section{Plant material}

The aerial parts of Tetraclinis articulata were collected from the drill Zakour, northeast of the capital of the wilaya of Mascara (western Algeria) at $800 \mathrm{~m}$ above sea level during june 2016, and identified by Pr BELGHARBI Benameur and Pr RIGHI Kada from Mascara University.

\section{Preparation of extracts}

The air-dried powdred parts $(1000 \mathrm{~g})$ of Tetraclinis articulata were macerated three times in boiling methanolic solution (70\%). The $\mathrm{MeOH}$ extract was concentrated to dryness, the residue was dissolved in boiling water $(600 \mathrm{ml})$ after filtration, the residue was extracted successively three times with DCM, AcOEt and n-butanol $(3 \times 200 \mathrm{ml})$ to give $1.100 ; 6.192$ and $31.146 \mathrm{~g}$ of the respective residues. Solvents were evaporated and the residues of each extract were dissolved in small volumes of methanol.

\section{Animals}

The study used male and female albinos Swiss mice weighing (18-24 g), were supplied by the animal house of pharmacy department of Constantine (Algeria). Animals were housed in standard propylene cages with wire mesh top and maintained under standard conditions (temperature $23 \pm 1.0$ ) ${ }^{\circ} \mathrm{C}$, humidity $55 \pm 1.0 \%, 12 \mathrm{~h}$ light $/ 12 \mathrm{~h}$ dark cycle).

\section{Biological activities}

\section{Anti-ulcéreuse activity}

Mice were divided into 3 experimental groups, each of 6 animals. Group 1 received the vehicle $(5 \mathrm{ml} / \mathrm{kg})$ and served as control group, group 2 administered aspirin $(700 \mathrm{mg} / \mathrm{kg})$ and served as reference drug group, the butanol extract of Tetraclinis articulata were administered at dose 400 $\mathrm{mg} / \mathrm{kg}$ to mice of group 3. All medication was administered orally. Once daily for consecutive days, the first doses were administrated in all groups one hour after colitis induction with $2 \mathrm{ml}(4 \%, \mathrm{v} / \mathrm{v})$ acetic acid in saline. At the end of the experiment; animals were sacrificed. Colonic segments were excised, opened along its mesenteric border, washed with saline, and were used for macroscopic scoring. The ulcer index (UI) was obtained from the sum of the scores of all lesions for each stomach, and the mean ulcer index (UI mean) was calculated for each group, percent ulcer inhibition of the samples was determined using the equation: [9].

\section{$\%$ ulcer inhibition $=100 \times($ UI mean control- UI mean sample $) /$ UI mean control}

\section{Antidiarrhoeal activity}

Mice were divided into 3 groups of six animals each and were fasted for $18 \mathrm{~h}$ with free access to water. The first group (control group) received normal saline $(\mathrm{NaCl} 0,9 \%)$ orally, while the second, was given the plant extract orally at doses of $5 \mathrm{mg} / \mathrm{kg}$ body weight, The third group received $0,5 \mathrm{ml}$ of 51

Corresponding author: ababsapharm@gmail.com 
the standard drug loperamide ( $5 \mathrm{mg} / \mathrm{kg}$ body weight). After 30 minutes, each animal was give $2 \mathrm{ml}$ of castrol oil orally, after 60 minutes each animal was given $1 \mathrm{~mL}$ of charcoal meal via the oral route. After anesthesia with chloroform, all animals were sacrificed after $60 \mathrm{~min}$ by opening the abdomen, and the distance covered by the charcoal meal in the intestine, from the pylorus to the caecum, was measured and expressed as the percentage of distance moved [10].

Percentage of transit inhibition $=100 \times\left(T_{0}-T_{1}\right) / T_{0}$

\section{$T_{0}$ : Total length of intestine.}

\section{$T_{1}$ : Charcoal distance of test group.}

\section{Resultats and discussions}

The butanolic extract of Tetraclinis articulata (BETA) showed anti-ulcereuse activity with exhibiting more than $\mathbf{7 0 \%}$ inhibition; this activity may be due to the phytochemicals compounds they contain (Table 1).

The same extract of $(T A)$ significantly decreased the propulsion of charcoal meal in rat gastrointestinal tracts by $68,18 \%$ compared to the negative control $20,69 \%$. A similar reduction in the gastrointestinal transit of charcoal meal in rats was achieved with Loperamide hate $(\mathbf{6 0 , 1 6} \%)$ (Table 2).

Table 1: Gastroprotective activity of Tetraclinis articulata in acetic acid induced in mice

\begin{tabular}{|c|c|c|}
\hline Groups & Ulcer Index & \% Ulcer Inhibition \\
\hline Group 1: Solvent & 6,02 & - \\
\hline Group 2: Aspirin & 1,12 & $\mathbf{8 1 , 3 9 \%}$ \\
\hline Group 3 : Sample (BETA) & $\mathbf{1 , 3 6}$ & $\mathbf{7 7 , 4 0 \%}$ \\
\hline
\end{tabular}

Table 2: Effects of a butanol extract of Tetraclinis articulata (TA) on the intestinal transit of charcoal meal in mice

\begin{tabular}{|l|l|l|l|}
\hline \multicolumn{1}{|c|}{ Groups } & $\begin{array}{l}\text { Total distance of } \\
\text { intestine }(\mathbf{c m})\end{array}$ & $\begin{array}{l}\text { Distance travelled by } \\
\text { charcoal }(\mathbf{c m})\end{array}$ & $\begin{array}{l}\text { Inhibition of mobility } \\
(\mathbf{\%})\end{array}$ \\
\hline Normal saline & 43.5 & 34.5 & $20.69 \%$ \\
\hline Loperamide & 42,25 & 16.83 & $60,16 \%$ \\
\hline butanol extract of (TA) & $\mathbf{4 4 . 2 5}$ & $\mathbf{1 4 , 0 8}$ & $\mathbf{6 8 , 1 8 \%}$ \\
\hline
\end{tabular}

\section{Conclusion:}

Our results demonstrate that the butanolic extract of Tetraclinis articulata (TA) Contains bioactive natural substances with antidiarrhoeal properties. These attributes may provide a rationale for the use of TA in diarrhoea management by traditional healers.

The present study indicates that butanolic extract of (TA) leaves administration attenuated aspirin-induced gastric ulcer, the results obtained supported the beneficial effects of (TA) in preventing the development of gastric ulcer, thus opening the possibility of its usage as an alternative therapy to gastric ulcer.

52

Corresponding author: ababsapharm@gmail.com

DOI: 10.2478/asn-2019-0007

C2019 “K. Preslavsky”University of Shumen. All rights reserved 


\section{References}

[1] Benabid, A., "Etude écologique, phytosociologique et sylvopastorale de la Tetraclinaie de l'Amsittene", Thèse de doctorat, université d'Aix-Marseille III, 1976, 3-4.

[2] Bellakhdar, J.; Honda, W., MikiHerb-Drugs and Herbalists in the Maghrib, Institute of the Study of Languages and Cultures of Asia and Africa, Toky, 1982, 13.

[3] Bellakhdar, J.; Claisse, R.; Fleurentin, J.; Yaunos, C., Repertory of standard herbal drugs in the Moroccan pharmacopoeia, 1991, 35,123-143.

[4] Bourkhiss, M.; Ouhssine, M.; Hnach, A.; Amechrouq, A.; Chaouch, B., MarocPhys. Chem. News, 2007, 35, 128-132.

[5] Bourkhiss, M.; Ouhssine, M.; Hnach, A.; Satrani, B.; Farah, A., Bull. Soc. Pharm. Bord, 2007, $146,75-84$.

[6] Bourkhiss, M. ; Hnach, A. ; Lakhlifi, T. ; Ouhssine, M.; Satrani, B., Bull. Soc. Roy. Sci. Liège, 2010, 79, 4-11.

[7] Ziyyat, H. ; Legssyer, A. ; Mekhfi, H. ; Dassoili, A. ; Serhrouchn, M. ; Benjelloun, W., Journal of Ethnopharmacology, 1997, 58, 45-54.

[8] Claisse, R., Pharmacopée traditionnelle au Maroc: marché populaire de Yacoub El Mansour. Actes du Premier Colloque Européen d'Ethnopharmacologie, 1990, 448-449.

[9] El Meligy, R. M.; Awad, A.; Kenawy, S., Prophylactic and curative anti-ulcerative colitis activity and the possible mechanisms of action of some desert plants, J. Enzyme Inhib. Med. Chem., 2015, 30, 250-258

[10] Pazhani, G.; Subramanian, N.; Arunchalam, G., Antidiarrheal potential of elephantopus scaber Linn leaf extract, Ind. drugs, 2001, 269-271. 